\title{
Isolasi Bakteri Resisten Arsen pada Sedimen Tanah di Muara Sungai Buyat
}

\author{
${ }^{1}$ Ivana C. Nainggolan \\ ${ }^{2}$ Fatimawali \\ ${ }^{2}$ Widdhi Bodhi
}

\author{
${ }^{1}$ Program Studi Pendidikan Dokter Fakultas Kedokteran Universitas Sam Ratulangi Manado \\ ${ }^{2}$ Bagian Kimia Fakultas Kedokteran Universitas Sam Ratulangi Manado \\ Email: 15011101034@student.unsrat.ac.id
}

\begin{abstract}
Arsenic, a toxic element to the body, is commonly found in mining waste. Buyat is known as a mining location (especially gold mine) which dumps mining waste in the form of tailings into the sea through the Buyat River. A mine should process the degradation of waste from a very toxic form into a less toxic form before disposing the waste into the sea. However, this process is often overlooked by artisanal miner because it consumes considerable production cost. Waste containing toxic arsenic gradually accumulates into sediments in the ocean, so bacteria in the environment begin to develop a mechanism of resistance to arsenic. This study was aimed to determine the types of arsenic-resistant bacteria isolated from sediment at Buyat estuary using conventional bacterial identification methods, including morpho-logical, physiological, and biochemical tests. Nine bacterial isolates were treated with arsenic stress at 5 ppm, 10 ppm, 20 ppm, 40 ppm, 80 ppm, 100 ppm, 300 ppm, 500 ppm, and $1000 \mathrm{ppm}$. The results showed several bacteria that could grow even in conditions containing as much as $1000 \mathrm{ppm}$ of arsenic, namely Klebsiella, Staphylococcus, Aeromonas, Clostridium, Bacillus, Hafnia, and Escherichia. Conclusion: In the sediment of Buyat estuary we found seven genera of bacteria, as follows: Klebsiella, Staphylococcus, Aeromonas, Clostridium, Bacillus, Hafnia and Escherichia.
\end{abstract}

Keywords: Arsenic-resistant bacteria, Buyat River, sediment, $\mathrm{As}_{2} \mathrm{O}_{3}$

\begin{abstract}
Abstrak: Arsen ialah salah satu jenis unsur yang bersifat toksik bagi tubuh dan merupakan salah satu hasil limbah pertambangan. Buyat merupakan salah satu lokasi pertambangan (terutama tambang emas) yang membuang limbah pertambangannya berupa tailings ke laut. Limbah tersebut dialirkan melalui Sungai Buyat. Pertambangan yang resmi harus melakukan proses degradasi arsen dari yang sangat toksik menjadi kurang toksik terlebih dahulu sebelum membuang limbah ke laut, namun proses ini sering diabaikan oleh pertambangan rakyat karena memakan biaya produksi yang cukup besar. Limbah yang mengandung arsen toksik lama-kelamaan terakumulasi menjadi sedimen di laut, sehingga bakteri di lingkungan tersebut mulai mengembangkan mekanisme resistensi terhadap arsen. Penelitian ini bertujuan untuk mengetahui jenis bakteri resisten arsen yang diisolasi dari sedimen di muara Sungai Buyat menggunakan metode identifikasi bakteri konvensional. Terdapat 9 isolat bakteri yang diberi perlakuan stres arsen pada 5 ppm, 10 ppm, 20 ppm, 40 ppm, 80 ppm, 100 ppm, 300 ppm, 500 ppm, dan $1000 \mathrm{ppm}$. Hasil penelitian mendapatkan beberapa jenis bakteri yang dapat bertumbuh bahkan pada kondisi mengandung arsen sebanyak 1000 ppm, yaitu genus Klebsiella, Staphylococcus, Aeromonas, Clostridium, Bacillus, Hafnia, dan Escherichia. Simpulan: Pada sedimen tanah di muara Sungai Buyat diidentifikasi tujuh genus bakteri, yaitu Klebsiella, Staphylococcus, Aeromonas, Clostridium, Bacillus, Hafnia, dan Escherichia.
\end{abstract} Kata kunci: bakteri resisten arsen, Sungai Buyat, sedimen, $\mathrm{As}_{2} \mathrm{O}_{3}$ 
Di Sulawesi Utara terdapat beberapa pertambangan, baik tambang yang memiliki izin ataupun tambang rakyat yang diolah oleh masyarakat. Salah satu lokasi yang cukup sering didengar sebagai lokasi pertambangan ialah Buyat. Hasil sampingannya berupa limbah pertambangan yang dibuang ke laut di Teluk Buyat. ${ }^{1}$ Proses pengolahan bahan tambang di Buyat menggunakan dan menghasilkan logamlogam berat, salah satunya ialah arsen. Arsen saat ini dapat diperoleh dari hasil sampingan proses peleburan biji tembaga, timah, kobalt dan emas, yaitu Arsenik Trioksida $\left(\mathrm{As}_{2} \mathrm{O}_{3}\right)$. Senyawa ini diketahui bersifat toksik. Bila terhirup dapat menyebabkan iritasi saluran napas, disertai nyeri tenggorok, batuk dan edema paru. Jika tertelan bisa menyebabkan gejala gastrointestinal yang hebat. Jika terjadi paparan jangka panjang dapat menyebabkan keracunan arsenik kronis (arsenikosis).,

Penelitian oleh Shepherd et al. ${ }^{4}$ melaporkan bahwa terdapat konsentrasi arsen pada sedimen di Teluk Buyat di kedalaman $10 \mathrm{~cm}$ sebanyak 2,25 mg/L. Pembuangan limbah pertambangan terutama arsen ke laut menjadi salah satu penyebab adanya kandungan arsen dalam sedimen. Dalam limbah industri pertambangan yang dibuang dapat mengandung sekitar 590-600 ppm arsen. ${ }^{5}$ Angka ini bisa menjadi berbahaya bagi lingkungan jika bahan arsen dibuang tanpa melalui pengolahan terlebih dahulu agar bisa didegradasi dari bentuk yang lebih toksik menjadi ke bentuk kurang toksik.

Proses degradasi dan pengaturan pembuangan limbah tambang kadang diabaikan oleh tambang rakyat karena memakan biaya produksi yang besar. Limbah pertambangan langsung dibuang ke laut melalui sungai dalam bentuk lumpur yang lamakelamaan terkumpul dan mengendap di sungai menjadi sedimen. Selain itu terjadi juga pencemaran lingkungan oleh arsen toksik yang terkandung dalam limbah pertambangan tadi.

Bakteri memiliki kemampuan memetbolisme limbah tambang sehingga bentuk kompleks dan toksik bisa menadi bentuk yang sederhana dan kurang toksik. Proses yang dapat dilakukan bakteri berupa oksidasi-reduksi, metilasi dan demetilasi. ${ }^{6}$ Namun bakteri yang bisa melakukan mekanisme ini hanyalah bakteri yang dapat bertahan hidup dalam lingkungan dengan stres arsen tinggi.

Tidak semua bakteri dapat bertahan hidup di dalam situasi dengan stres arsen, namun bakteri dapat menyesuaikan diri dengan lingkungan secara fisiologik, yaitu adaptif, kemudian terjadi proses biokimia yang menyebabkan bakteri tersebut menjadi toleran. Dalam prosesnya bakteri dapat mati atau bertahan. Lama-kelamaan dapat terjadi proses mutasi DNA yang membuat bakteri bisa bertahan sepenuhnya dalam kondisi lingkungan dengan stress arsen. Bakteri yang dapat melakukan hal tersebut disebut sebagai bakteri resisten arsen.

\section{METODE PENELITIAN}

Penelitian ini menggunakan metode deskriptif-eksploratif. Pengambilan sampel dilakukan di Teluk Buyat. Analisis lanjut untuk isolasi dan identifikasi bakteri dilakukan di Laboratorium Farmasi Fakultas Matematika dan Ilmu Pengetahuan Alam (FMIPA) Universitas Sam Ratulangi sejak bulan September sampai November 2018.

Sampel penelitian yang digunakan ialah koloni bakteri yang resisten terhadap arsen yang diisolasi dari sedimen tanah di daerah muara Sungai Buyat, dimana terjadi pertemuan antara air sungai dan air laut. Sampel diambil pada jam 10.00-12.00 yang merupakan waktu air laut tersurut, untuk mempermudah pengambilan sampel kemudian sedimen tersebut dimasukkan ke dalam botol steril. Untuk menjaga kondisi sedimen maka sampel disimpan dalam cool box selama perjalanan.

Sebanyak 1 gr sampel sedimen dilarutkan dalam $10 \mathrm{~mL} \mathrm{NaCl}$, lalu disentrifugasi selama 10 menit. Larutan arsenite dibuat dengan melarutkan $100 \mathrm{mg} \mathrm{As}_{2} \mathrm{O}_{3}$ ke 100 $\mathrm{mL}$ akuades hangat dengan suhu $50^{\circ} \mathrm{C}$. Media pertumbuhan Luria Bertani agar dibuat dengan mencampurkan $\mathrm{NaCl} 1 \%$, Tripton 1\%, Agar 1.5\%, Yeast Extract $0.5 \%$ yang dilarutkan dalam $1000 \mathrm{~mL}$ 
aquadest. Media LB dicampurkan dengan $\mathrm{As}_{2} \mathrm{O}_{3}$ dengan konsentrasi 5 ppm,10 ppm, $20 \mathrm{ppm}, 40 \mathrm{ppm}, 80 \mathrm{ppm}, 100 \mathrm{ppm}, 300$ ppm, 500 ppm, 1000 ppm.

Sampel sedimen yang sudah disiapkan dimasukkan kedalam media LB yang sudah dibuat, kemudian diinkubasi selama 24 jam pada suhu $37^{\circ} \mathrm{C}$. Setelah bakteri tumbuh, koloni bakteri selanjutnya dimurnikan pada media LB agar yang sudah mengandung $\mathrm{As}_{2} \mathrm{O}_{3}$ dengan konsentrasi yang sudah ditentukan, lalu dilakukan metode streak plate dengan menggoreskan jarum Ose yang terdapat bakteri pada media LB agar.

Untuk identifikasi bakteri konvensional dilakukan uji morfologi berupa pewarnaan Gram, uji fisiologi berupa motilitas di nutrient agar, dan uji biokimia berupa indol, $\mathrm{H}_{2} \mathrm{~S}$, fermentasi karbohidrat, katalase, sitrat, dan lisin. Hasil uji tersebut dicocokkan dengan Bergey's Manual of Systematic Bacteriology ${ }^{7}$ untuk menentukan genus.

\section{HASIL PENELITIAN \\ Pertumbuhan Koloni Bakteri}

Pada proses pemilihan isolat bakteri, dipilih koloni berdasarkan bentuk dan luas permukaan yang tampak pada media LB agar. Setelah diberi tanda, koloni tersebut digoreskan pada media baru secara terpisah, kemudian diberi label sesuai jenis sampel dan konsentrasi arsennya. Pemberian nama pada sampel berupa titik lokasi dan konsentrasi arsen yang terkandung di media, yaitu BM 0 (Buyat Muara konsentrasi arsen 0 ppm), BM 5, BM 10, BM 20, BM 40, BM 80, BM 100, BM 300, BM 500, dan BM 1000.

Tedapat pertumbuhan koloni bakteri pada cawan Petri di setiap konsentrasi namun koloni yang terbentuk jumlahnya berbeda pada setiap konsentrasi arsen yang diberikan. Pada konsentrasi 5 ppm partumbuhan koloni masih cukup banyak dan merata di seluruh permukaan cawan petri. Pada konsentrasi 500 ppm dan 1000 ppm, terdapat penurunan jumlah koloni, terutama pada konsentrasi 1000 ppm koloni yang terbentuk sangat tipis dibanding konsentrasi yang lebih rendah. a.)

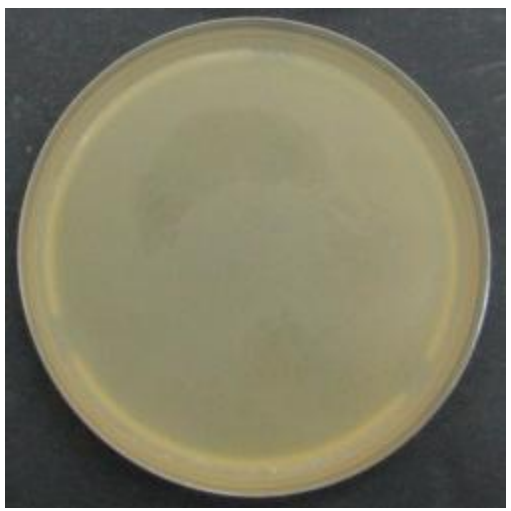

b.)

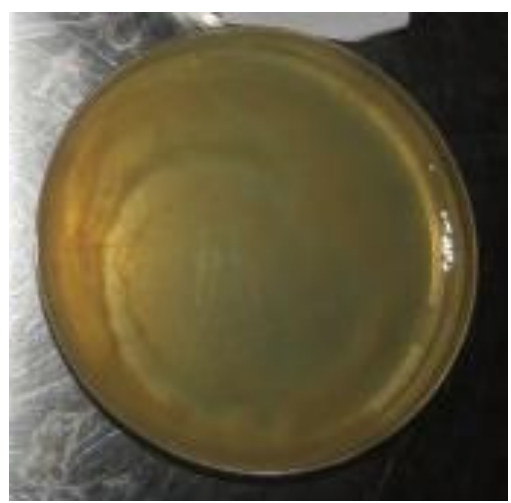

c.)

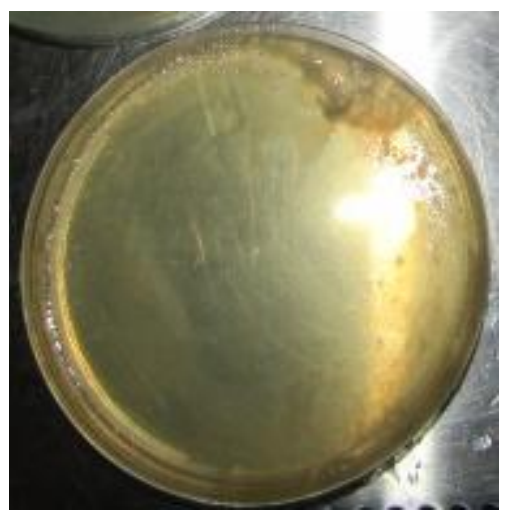

Gambar 1. Pertumbuhan koloni a) 5 ppm; b) 500 ppm; c) 1000 ppm

\section{Hasil Identifikasi Bakteri}

Morfologi bakteri diketahui melalui pewarnaan Gram. Isolat dengan kode 5, BM 10, BM 100, BM 500, BM 1000 ialah bakteri bentuk basil Gram negatif. Isolat dengan kode BM 20 dan BM 40 ialah bakteri bentuk basil Gram positif, sedangkan isolat dengan kode BM 80 dan BM 300 ialah bakteri bentuk kokus Gram positif.

Sebanyak 9 isolat dilakukan uji fisiologi (motilitas) pada media nutrien agar, dan didapatkan bahwa seluruh isolat menunjukkan hasil negatif, dimana tidak 
terjadi penyebaran pertumbuhan bakteri dari tempat penusukan.

Uji fermentasi karbohidrat dilakukan pada media TSI (Triple Sugar Iron) agar. Pada isolat dengan kode BM 5, BM 10, BM 20, dan BM 40 didapatkan bahwa bakteri dapat memfermentasi glukosa. Pada isolat dengan kode BM 80, BM 100, BM 300, dan BM 500 didapatkan bahwa bakteri dapat memfermentasi glukosa dan menghasilkan gas. Isolat dengan kode BM 1000 tidak dapat memfermentasikan karbohidrat apapun.

$\mathrm{H}_{2} \mathrm{~S}$ juga sekaligus dipantau pada uji ini dengan melihat adanya perubahann warna menjadi hitam. Hasil yang didapatkan ialah seluruh isolat tidak dapat memproduksi $\mathrm{H}_{2} \mathrm{~S}$.

Uji indol dilakukan pada media nutrien agar yang sebelumnya dipakai untuk uji motilitas dengan cara meneteskan reagen Kovac. Pada isolat BM 5, BM 10, BM 20, BM 40 didapatkan hasil uji Indol negatif. Isolat BM 80, BM 100, BM 300, BM 500, dan BM 1000 didapatkan hasil uji Indol positif.

Uji sitrat menunjukkan hasil positif pada seluruh isolat, kecuali pada isolat dengan kode BM 5 menunjukkan warna hijau lumut, yang menggambarkan uji sitrat negatif.

Uji lisin dilakukan pada 9 jenis isolate dan didapatkan hasil uji positif pada isolat BM 5, BM 10, dan BM 1000. Isolat dengan kode BM 20, BM 40, BM 80, BM 100, BM 300, dan BM 500 menunjukkan hasil uji lisin negatif.

Uji katalase menunjukkan hasil negatif pada isolat dengan kode BM 40. Isolat lainnya menunjukkan hasil uji katalase positif.

Hasil uji secara keseluruhan dirangkum dalam Tabel 1. Seluruh isolat di atas kemudian dicocokkan dengan Bergey's Manual of Systematic Bacteriology, ${ }^{7}$ untuk menentukan genus dari bakteri resisten arsen. Genus yang didapatkan dijabarkan pada Tabel 2.

Tabel 1. Hasil uji isolat bakteri resisten arsen dengan metode identifikasi bakteri konvensional

\begin{tabular}{lccccccccc}
\hline \multirow{2}{*}{ Uji } & \multicolumn{8}{c}{ Kode isolat bakteri resisten arsen } \\
\cline { 2 - 10 } identifikasi & BM5 & BM10 & BM20 & BM40 & BM80 & BM100 & BM300 & BM500 & BM 1000 \\
\hline Morfologi & (-) B & (-) B & $(+)$ B & (+) B & (+) K & $(-)$ B & $(+)$ K & $(-)$ B & $(-)$ B \\
F. Karbohidrat & g & g & g & g & g (gas) & g (gas) & g (gas) & g (gas) & g \\
Motil & - & - & - & - & - & - & - & - & - \\
Indol & - & - & - & - & + & + & + & + & + \\
Sitrat & - & + & + & + & + & + & + & + & + \\
Lysin & + & + & - & - & - & - & - & - & + \\
$\mathrm{H}_{2} \mathrm{~S}$ & - & - & - & - & - & - & - & - & - \\
Katalase & + & + & + & - & + & + & + & + & + \\
\hline
\end{tabular}

B: Basil; K: Kokus; g: glukosa; f: fruktosa; 1: laktosa; gas: ada produksi gas dari hasil fermentasi karbohidrat.

Tabel 2. Genus bakteri resisten arsen

\begin{tabular}{cc}
\hline Kode isolat & Genus \\
\hline BM 5 & Escherichia \\
BM 10 & Hafnia \\
BM 20 & Bacillus \\
BM40 & Clostridium \\
BM 80 & Staphylococcus \\
BM 100 & Aeromonas \\
BM 300 & Staphylococcus \\
BM 500 & Klebsiella \\
BM 1000 & Klebsiella \\
\hline
\end{tabular}




\section{BAHASAN}

Bakteri memiliki kemampuan untuk mereduksi arsen, tergantung dari kemampuan dan jenis bakterinya. Tentunya bakteri yang bisa melakukan hal tersebut ialah bakteri yang dapat hidup dalam kondisi dengan stres arsen tinggi, yang disebut bakteri resisten arsen. Namun sampai saat ini belum ada definisi pasti pada konsentrasi arsen berapakah yang dapat disebut konsentrasi bakteri resisten arsen. Uji resisten dilakukan mulai dari konsentrasi 5 ppm hingga 1000 ppm. Seluruh isolat yang diambil dari sampel tumbuh pada pemberian $\mathrm{As}_{2} \mathrm{O}_{3}$ konsentrasi 5 ppm, 10 ppm, 20 ppm, 40 ppm, 80 ppm, 100 ppm, 300 ppm, 500 ppm, dan 1000 ppm. Pada konsentrasi 5 ppm, pertumbuhan koloni merata dan agak tebal. Seiring dengan peningkatan konsentrasi arsen, didapatkan bahwa pada konsentrasi 500 ppm jumlah koloni mulai menurun dan menjadi sangat tipis pada konsentrasi 1000 ppm.

Klebsiella merupakan bakteri Gram negatif berbentuk basil pendek. Bakteri bersifat non motil dengan lisin positif. Bakteri ini hidup dalam keadaan fakultatif anaerob. Klebsiella terdapat dalam berbagai lingkungan. Strain dari genus ini dapat ditemukan di air permukaan, limbah, tanah, dan permukaan tanaman. Klebsiella juga hidup pada permukaan mukosa hewan dan manusia. Pada manusia bakteri ini dapat ditemukan pada saluran napas, pencernaan dan urogenital. ${ }^{8}$

Staphylococcus merupakan bakteri Gram positif berbentuk kokus. Bakteri ini dapat ditemukan berdiri sendiri ataupun berkelompok dan membentuk kumpulan seperti buah anggur. Bakteri ini menunjukkan hasil positif pada uji katalase, dan bersifat fakultatif anaerob. Genus Staphylococcus ditemukan hidup di kulit dan kelenjarnya, juga pada membran mukosa manusia, mamalia dan burung sebagai bakteri oportunistik. Di dalam alam sendiri bakteri ini dapat ditemukan pada tanah, air, permukaan tanaman, dan juga produk makanan (seperti kuning telur yang belum matang sempurna) yang dapat menimbulkan penyakit pada manusia.
Aeromonas merupakan bakteri Gram negatif berbentuk basil yang bersifat fakultatif anaerob. Bakteri ini terdapat pada lingkungan perairan, air sumur, air payau, dll. Juga dapat ditemukan pada hewan yang hidup di perairan seperti ikan, katak, dan hewan yang mengonsumsi air dari lokasi yang sudah terkandung bakteri tersebut. Pada manusia bakteri ini dapat bersifat patologik dan menimbulkan beberapa penyakit seperti gastroenteritis. ${ }^{10}$

Escherichia merupakan bakteri Gram negatif berbentuk basil. Bakteri ini dapat bersifat motil maupun non motil, tergantung spesiesnya. Escherichia hidup dalam kondisi aerobik, namun dapat hidup dalam kondisi fakultatif anaerob. Genus ini dapat memfermentasi laktosa dan memberikan hasil positif pada uji lisin hampir pada seluruh spesiesnya. Bakteri ini tidak dapat memroduksi $\mathrm{H}_{2} \mathrm{~S}$. Escherichia banyak hidup pada saluran cerna namun kadangkadang dapat bersifat patologik dan menyebabkan diare, infeksi saluran kemih (ISK), dll. Sebagai contoh yaitu bakteri Escherichia coli yang menghasilkan enterotoksin dapat menimbulkan diare pada manusia. ${ }^{11}$

Bacillus merupakan bakteri Gram positif berbentuk basil. Genus ini dapat bersifat motil maupun non motil. Uji katalase positif hampir pada seluruh spesienya. Kebanyakan bersifat aerobik, namun dapat hidup sebagai fakultatif anaerob. Umumnya bakteri ini diisolasi dari tanah, namun juga terdapat di air, makanan, dan spesimen klinis. $^{12}$

Clostridium merupakan bakteri Gram positif berbentuk basil, umumnya bersifat obligatif anaerob. Genus ini menghasilkan uji katalase negatif. Banyak spesiesnya menghasilkan eksotoksin sehingga bersifat patogen. ${ }^{13}$

Hafnia merupakan bakteri Gram negatif berbentuk basil, umumnya bersifat motil pada suhu $30^{\circ} \mathrm{C}$, namun dapat juga non motil. Bakteri ini bersifat fakultatif anaerob, dan katalase positif. Genus ini hanya memiliki satu spesies heterogen, yaitu Hafnia alvei. Bakteri ini dapat ditemukan pada feses manusia sehat dan dalam keadaan patologik pada gastroenteritis. ${ }^{14}$ 


\section{SIMPULAN}

Berdasarkan hasil penelitian ini dapat disimpulkan bahwa terdapat bakteri resisten arsen pada sedimen tanah di muara Sungai Buyat yaitu genus Klebsiella, Staphylococcus, Aeromonas, Clostridium, Bacillus, Hafnia dan Escherichia yang ditentukan berdasarkan uji morfologi, fisiologi, dan biokimia yang dicocokkan dengan Bergey's Manual of Systematic Bacteriology. ${ }^{7}$

\section{SARAN}

Disarankan agar masyarakat meninjau kembali proses pengolahan limbah pertambangan di Buyat karena telah didapatkan adanya bakteri resisten arsen pada sedimen tanah di muara Sungai Buyat. Disarankan juga untuk melakukan identifikasi isolat bakteri menggunakan metode 16sRNA agar lebih mudah dan lebih akurat.

\section{DAFTAR PUSTAKA}

1. Newmount Mining Corporation. Newmount Our Voice Blog. [Online]. 2017. [cited 2018 Nov 02]. Available from: https://ourvoice.newmount.com/2017/0 9/21/new-study-reaffirms-tailingsresponsibility-managed-at-buyat-bayin-indonesia/.

2. Badan POM RI. Sentra Informasi Keracunan Nasional (SiKer Nas). [Online]. Badan POM RI, 2010 [cited 2018 Oct 10]. Available from: http://ik.pom.go.id/ v2014/katalog/arsenik.pdf.

3. World Health Organization. Ten chemical of major public health concern. [Online]. 2016 [cited 2018 Sep 20. Available from: https: //www.who.int/ipcs/ assessment/public_health/chemicals_ph c/en.

4. Sheperd T, Rumengan I, Sahami A. Postdepositional behaviour of mercury and arsenic in submarine mine tailings deposited in Buyat Bay, North Sulawesi, Indonesia. Mar Environ Res. 2018;137:88-97.

5. Blackwood GM, Edinger EN. Mineralogy and trace element relative solubility patterns of shallow marine sediments affected by submarine tailings disposal and artisanal gold mining, BuyatRatototok district, North Sulawesi,
Indonesia. Environmental Geology. 2006;52(4):803-18.

6. Satyapal GK, Rani S, Kumar M, Kumar N. Potential role of arsenic resistant bacteria in bioremediation: current status and future prospects. J Microb Biochem Technol. 2016;8(3):256-8.

7. Holt JG, Krieg NR, Sneath PHA, Staley JT, Williams ST. Berge's Manual of Determinative Bacteriology (9th ed). Hensyl WR, editor. Baltimore, Maryland: Williams \& Wilkins, 1994.

8. Grimont PAD, Grimont F. Klebsiella. In: Whitman WB, Rainey F, Kämpfer P, Trujillo ME, Chun J, DeVos P, et al, editors. Bergey's Manual of Systematics of Archaea and Bacteria. New Jersey: Wiley, 2015.

9. Schleifer KH, Bell JA. Staphylococcus. In: Whitman WB, Rainey F, Kämpfer P, Trujillo ME, Chun J, DeVos P, et al, editors. Bergey's Manual of Systematics of Archaea and Bacteria. New Jersey: Wiley, 2015.

10. Carnahan AM, Joseph SW. Aeromonas. In: Whitman WB, Rainey F, Kämpfer P, Trujillo ME, Chun J, DeVos P, et al, editors. Bergey's Manual of Systematics of Archaea and Bacteria. New Jersey: Wiley, 2015.

11. Scheutz F, Strockbine NA. Escherichia. In: Whitman WB, Rainey F, Kämpfer P, Trujillo ME, Chun J, DeVos P, et al, editors. Bergey's Manual of Systematics of Archaea and Bacteria. New Jersey: Wiley, 2015.

12. Logan NA, DeVos P. Bacillus. In: Whitman WB, Rainey F, Kämpfer P, Trujillo ME, Chun J, DeVos P, et al, editors. Bergey's Manual of Systematics of Archaea and Bacteria. New Jersye: Wiley, 2015.

13. Rainey FA, Small A. Clostridium. In: Whitman WB, Rainey F, Kämpfer P, Trujillo ME, Chun J, DeVos P, et al, editors. Bergey's Manual of Systematics of Archaea and Bacteria. New Jersey: Wiley, 2015.

14. Sakazaki R. Hafnia. In: Whitman WB, Rainey F, Kämpfer P, Trujillo ME, Chun J, DeVos P, et al, editors. Bergey's Manual of Systematics of Archaea and Bacteria. New Jersey: Wiley, 2015. 
